\title{
MORPHOLOGICAL CHARACTERS, PLANT PHENOLOGY AND YIELD OF SPRING BARLEY (Hordeum sativum L.) DEPENDING ON CULTIVAR PROPERTIES AND SOWING DATE
}

\author{
Kazimierz Noworolnik \\ Institute of Soil Science and Plant Cultivation, State Research Institute \\ Czartoryskich 8, 24-100 Puławy, Poland \\ e-mail: knoworolnik@iung.pulawy.pl
}

Received: 12.10.2011

\begin{abstract}
During the period 2008-2010, microplot experiments on spring barley were carried out in the experimental field of the Institute of Soil Science and Plant Cultivation - State Research Institute in Puławy, on a good wheat soil complex. The following cultivars were compared: 'Conchita', 'Kormoran', 'Rufus', 'Skald', 'Skarb' (2008-2009) as well as 'Afrodite', 'Aliciana', 'Bordo', 'Skald', and 'Suweren' (2009-2010), in terms of their morphological characters determining grain yield and their response to sowing date: 7-12 April and 17-22 April.

Among the spring barley cultivars tested, there were large differences in productive tillering of plants, number of ears per unit area, and grain yield. Smaller differences related to number of grains per ear and 1000 grain weight. The cultivars 'Suweren' and 'Skarb' were characterized by high grain yield thanks to greater plant tillering and higher number of ears. The cultivar 'Bordo' was marked by the highest number of grains per ear, while cv. 'Kormoran' had the highest 1000 grain weight. A delayed sowing date caused a shortening of the growing season by 8-9 days and a shortening of all plant growth stages. This negatively affected number of ears per unit area and grain yield, but did not result in significant changes in number of grains per ear and 1000 grain weight.

'Suweren' and 'Skarb', i.e. cultivars with higher tillering ability, can be considered to be cultivars more tolerant to delayed sowing date.
\end{abstract}

Key words: Hordeum sativum L., cultivars, plant tillering, grain yield, phenological phases

\section{INTRODUCTION}

Barley is marked by the largest crop area in Poland among spring cereals. The increase in barley yields over the recent period has largely been an effect of the introduction of new more productive cultivars into farming practice. Potential grain yield of a given cultivar depends on various characters making up the plant growth habit. The productive tillering ability of plants, that is, their ability to produce an optimally large number of ears in the crop, is of special significance. Furthermore, ear productivity traits are also important. Intervarietal variation in morphological characters of barley may generate a different response of particular cultivars to major agronomic factors (fertilization as well as sowing date and seeding rate). Barley cultivars with higher tillering ability have been found to show a weaker response to increasing seeding rate $(\mathrm{P} \mathrm{e} \mathrm{c} \mathrm{i} \mathrm{o,}$ 1995; A u fh a m mer and Kubler, 1989; Pecio, 1995; N ow or o lnik, 2003, 2010 a). Barley cultivars with lower tillering ability have been observed to respond stronger to increased nitrogen fertilization rates by increasing yield (Lauer and Partridge, 1990; Conry, 1995; Now orolnik, 2003, 2010 b). However, there is a lack of information on different responses of new barley cultivars to delayed sowing date as expressed by plant morphological characters and grain yield. In Poland the frequent prolonged persistence of winter conditions forces delayed sowing time of spring cereals. Decreased yields of new barley cultivars with delayed sowing dates should be compared in relation to plant morphological characters that strongly affect grain yield. In the literature, there is also a lack of information on variations in productive tillering rate and number of grains per ear in spring barley cultivars as well as on the pattern of phenological phases of new barley cultivars depending on sowing date. In the cultivar experiments conducted by the Research Centre for Cultivar Testing in Stupia Wielka, grain yield, 1000 grain weight, and the degree of lodging were evaluated, but number of ears per unit 
area and number of grains per ear were not determined (N a jew ski, 2010).

The aim of the present study was to compare new barley cultivars in terms of their productive tillering ability, number of grains per ear, and 1000 grain weight as well as in terms of their response to delayed sowing date as expressed by plant morphological characters, grain yield, and the pattern of phenological phases.

The research hypothesis was that with delayed sowing date decreases in grain yield of the barley cultivars tested would be different, in association with different changes in the morphological characters (productive tillering rate, number of grains per ear, 1000 grain weight) of these cultivars. The cultivars with higher tillering ability and, moreover, characterized by a high number of grains per ear might presumably respond by a lower decrease in yield under the effect of delayed sowing time.

\section{MATERIALS AND METHODS}

During the period 2008-2010, microplot experiments on spring barley were carried out in the experimental field of the Institute of Soil Science and Plant Cultivation - State Research Institute in Puławy, on a good wheat soil complex. The following cultivars were compared: 'Conchita', 'Kormoran', 'Rufus', 'Skald', 'Skarb' (2008-2009) as well as 'Afrodite', 'Aliciana', 'Bordo', 'Skald', and 'Suweren' (2009-2010), in terms of their morphological characters determining grain yield and their response to sowing date: 7-12 April and 17-22 April.

The experiment was established in a field after potato as a split-plot design in 4 replications. Mineral fertilization, adjusted to soil macronutrient availability, was applied at the following rates on a per hectare basis: $\mathrm{N}-60 \mathrm{~kg}$; P- $28 \mathrm{~kg} ; \mathrm{K}-58 \mathrm{~kg}$. The seeding rate was 300 grains $\times \mathrm{m}^{-2}$. Number of ears per $1 \mathrm{~m}^{2}$, productive tillering rate, number of grains per ear, 1000 grain weight, and grain yield were determined. The beginning of particular phenological phases of barley plants was recorded and the length of the growing season was determined. The results were statistically analysed using analysis of variance and the significance of differences was determined by Tukey's test $(\mathrm{p}=0.05)$.

\section{RESULTS AND DISCUSSION}

The length of the growing season and the duration of individual phenological phases of spring barley plants were dependent on sowing date and weather conditions in particular years (Table 1). A delayed sowing date caused a shortening of the growing season by 8-9 days, which was attributable to the shortening of all plant growth stages. The growing season of spring barley in 2008 was longer by 9 days compared to 2010 . This resulted from lower rainfall and higher temperatures in 2010 in the months of April, June, and July.

Table 1.

Growth of spring barley depending on sowing date

\begin{tabular}{|c|c|c|c|c|c|c|}
\hline \multirow{5}{*}{ Plant growth stage } & \multicolumn{6}{|c|}{ Year } \\
\hline & \multicolumn{2}{|c|}{2008} & \multicolumn{2}{|c|}{2009} & \multicolumn{2}{|c|}{2010} \\
\hline & \multicolumn{6}{|c|}{ Sowing date } \\
\hline & 7-12 IV & $17-22$ IV & 7-12 IV & 17-22 IV & 7-12 IV & 17-22 IV \\
\hline & \multicolumn{6}{|c|}{ Number of days from sowing to the full growth stage } \\
\hline emergence & 12 & 9 & 13 & 12 & 12 & 11 \\
\hline tillering & 25 & 23 & 26 & 23 & 24 & 21 \\
\hline stem elongation & 46 & 41 & 45 & 41 & 42 & 38 \\
\hline heading & 65 & 60 & 64 & 59 & 62 & 58 \\
\hline milk stage & 73 & 67 & 76 & 71 & 72 & 67 \\
\hline dough stage & 95 & 89 & 97 & 91 & 92 & 85 \\
\hline full ripe & 110 & 102 & 106 & 97 & 101 & 93 \\
\hline
\end{tabular}

Among the morphological traits that determine grain yield, the largest differences between the spring barley cultivars in question related to number of ears per unit area and productive tillering rate. In the first experimental series (2008-2009), the cultivar 'Skarb' was characterized by the highest number of ears per $1 \mathrm{~m}^{2}$ and the highest productive tillering rate (Table 2). This cultivar was found to have a significantly higher number of ears per $1 \mathrm{~m}^{2}$ compared to the cultivars 'Skald' and 'Conchita'. Cv. 'Kormoran' showed a significantly higher number of ears than 'Conchita'. In the second experimental series (2009-2010), the cultivar 
'Suweren' produced a significantly higher number of ears per $1 \mathrm{~m}^{2}$ of all the cultivars (Table 3 ). The cultivars 'Afrodite' and 'Skald' showed a significantly higher number of ears than cv. 'Bordo'. Cv. 'Suweren' was characterized by the highest productive tillering rate, while this rate was the lowest in the case of 'Bordo'.

In the first experimental series, number of grains per ear was similar in the cultivars studied (not significant differences). Among the cultivars tested in the second experimental series, 'Bordo' was found to show a significantly higher number of grains per ear in relation to the following cultivars: 'Skald', 'Afrodite', and 'Suweren', whereas 'Aliciana' showed higher grain productivity than the cultivars 'Afrodite' and 'Suweren' (Table 3 ).

There were significant differences in 1000 grain weight between the cultivars tested only in the first experimental series (Table 2). Cv. 'Kormoran' showed significantly higher 1000 grain weight compared to 'Skald' and 'Rufus'. The cultivars 'Skarb' and 'Conchita' were also found to show significantly higher 1000 grain weight in relation to 'Rufus'. Among the cultivars tested in the second experimental series, a trend towards lower 1000 grain weight was observed in 'Suweren' compared to the other cultivars.

The study found distinct differences in grain yield between the spring barley cultivars, in particular between those tested in the period 2008-2009 (Table 2). Cv. 'Skarb' showed significantly higher grain yield than the cultivars 'Kormoran', 'Conchita', and 'Skald', while cv. 'Rufus' produced higher yield than 'Skald'. In the second experimental series, 'Suweren' produced significantly higher yield than the cultivars 'Afrodite' and 'Aliciana' (Table 3).

Table 2.

Comparison of morphological characters (determining grain yield) of spring barley cultivars, 2008-2009

\begin{tabular}{lcccccc}
\hline \multicolumn{1}{c}{ Character } & Conchita & Kormoran & Rufus & Skald & Skarb $^{\text {LSD }}$ & (0.05 \\
\hline Number of ears per $1 \mathrm{~m}^{2}$ & 924 & 1031 & 1025 & 997 & 1063 & 62 \\
Productive tillering rate & 3.25 & 3.60 & 3.67 & 3.48 & 4.07 & - \\
Number of grains per ear & 18.1 & 17.6 & 18.0 & 17.4 & 17.7 & n.s. \\
1000 grain weight $(\mathrm{g})$ & 48.1 & 48.9 & 45.4 & 46.3 & 48.2 & 2.5 \\
Grain yield $\left({\left.\mathrm{g} \times \mathrm{m}^{-2}\right)}\right.$ & 810 & 832 & 857 & 804 & 903 & 51 \\
\hline
\end{tabular}

Table 3.

Comparison of morphological characters (determining grain yield) of spring barley cultivars, 2009-2010

\begin{tabular}{lcccccc}
\hline \multicolumn{1}{c}{ Character } & Afrodite & Aliciana & Bordo & Skald & Suweren $^{\text {LSD }}$.05 \\
\hline Number of ears per $1 \mathrm{~m}^{2}$ & 923 & 894 & 860 & 922 & 1064 & 59 \\
Productive tillering rate & 3.48 & 3.15 & 2.94 & 3.26 & 3.82 & - \\
Number of grains per ear & 18.2 & 20.0 & 21.3 & 19.4 & 17.8 & 1.6 \\
1000 grain weight $(\mathrm{g})$ & 48.2 & 48.6 & 47.8 & 48.2 & 46.8 & n.s. \\
Grain yield $\left({\left.\mathrm{g} \times \mathrm{m}^{-2}\right)}\right.$ & 860 & 858 & 871 & 864 & 908 & 49 \\
\hline
\end{tabular}

Spring barley (on average for the cultivars) produced much higher yields under the conditions of early sowing time compared to late sowing time (Table 4). This was an effect of better productive tillering of earlier sown plants and thereby a higher number of ears per unit area, in spite of a trend towards a higher number of grains per ear in the case of late sowing date. The study found no effect of sowing date on 1000 grain weight. During the growing season, the failure rate for the spring barley crop was 5-6\% with early sowing date and $8-11 \%$ with delayed sowing date.

The individual cultivars responded with a different decrease in grain yield to delayed sowing date
(Table 5, 6). The cultivars 'Conchita' (2008-2009) as well as 'Aliciana' and 'Bordo' (2009-2010) showed a significant decrease in grain yield. In terms of grain yield, a weaker negative response to delayed sowing date was found in the cultivars 'Skarb', 'Rufus', and 'Kormoran' (2008-2009) as well as in 'Afrodite' and 'Suweren' (2009-2010). Cv. 'Skald' was characterized by a medium response to delayed sowing time.

Higher variations in productive tillering as well as lower variations in number of grains per ear and 1000 grain weight were found under the influence of sowing date and cultivar properties. Under the conditions of delayed sowing time, the productive tillering rate decreased most in the case of the cultivars 
'Conchita' (2008-2009) as well as 'Aliciana', 'Bordo', and 'Suweren' (2009-2010). A trend towards a decrease in the number of grains per ear under the effect of delayed sowing date was only observed in 'Rufus' and 'Kormoran' (2008-2009). The other cultivars, in particular 'Aliciana', 'Suweren', and 'Afrodite', responded to delayed sowing date by an increase in the number of grains per ear. A trend towards a decrease in 1000 grain weight with delayed sowing date was observed in the cultivars 'Afrodite' and 'Bordo', but a trend towards its increase in the cultivars 'Skarb', 'Rufus', 'Skald', and 'Suweren' (Tables 5, 6).

Table 4.

Effect of sowing date on the characters of spring barley (on average for the cultivars), 2008-2010

\begin{tabular}{cccccc}
\hline Sowing date & $\begin{array}{c}\text { Number of ears } \\
\text { per } 1 \mathrm{~m}^{2}\end{array}$ & $\begin{array}{c}\text { Productive tillering } \\
\text { rate }\end{array}$ & $\begin{array}{c}\text { Number of grains } \\
\text { per ear }\end{array}$ & $\begin{array}{c}1000 \text { grain } \\
\text { weight }(\mathrm{g})\end{array}$ & $\begin{array}{c}\text { Grain yield } \\
\left(\mathrm{g} \times \mathrm{m}^{-2}\right)\end{array}$ \\
\hline 7-12 IV & 1035 & 3.68 & 18.2 & 47.4 & 892 \\
$17-22 \mathrm{IV}$ & 897 & 3.25 & 18.8 & 48.2 & 815 \\
\hline LSD $_{0.05}$ & 61 & - & n.s. & n.s. & 57 \\
\hline
\end{tabular}

Table 5.

Effect of sowing date on the characters of spring barley cultivars tested in 2008-2009

\begin{tabular}{|c|c|c|c|c|c|}
\hline Cultivar & Sowing date & $\begin{array}{l}\text { Productive } \\
\text { tillering rate }\end{array}$ & $\begin{array}{c}\text { Number of grains } \\
\text { per ear }\end{array}$ & $\begin{array}{l}1000 \text { grain } \\
\text { weight }(\mathrm{g})\end{array}$ & $\begin{array}{l}\text { Grain yield } \\
\left(\mathrm{g} \times \mathrm{m}^{-2}\right)\end{array}$ \\
\hline Conchita & $\begin{array}{l}\text { 7-12 IV } \\
17-22 \text { IV }\end{array}$ & $\begin{array}{l}3.46 \\
2.98\end{array}$ & $\begin{array}{l}17.9 \\
18.2\end{array}$ & $\begin{array}{l}47.9 \\
48.2\end{array}$ & $\begin{array}{l}914 \\
706\end{array}$ \\
\hline Kormoran & $\begin{array}{l}7-12 \text { IV } \\
17-22 \text { IV }\end{array}$ & $\begin{array}{l}3.71 \\
3.50\end{array}$ & $\begin{array}{l}18.1 \\
17.0\end{array}$ & $\begin{array}{l}48.3 \\
49.4\end{array}$ & $\begin{array}{l}866 \\
798\end{array}$ \\
\hline Rufus & $\begin{array}{l}\text { 7-12 IV } \\
17-22 \text { IV }\end{array}$ & $\begin{array}{l}3.82 \\
3.53\end{array}$ & $\begin{array}{l}18.4 \\
17.9\end{array}$ & $\begin{array}{l}44.5 \\
46.4\end{array}$ & $\begin{array}{l}887 \\
825\end{array}$ \\
\hline Skald & $\begin{array}{l}7-12 \text { IV } \\
17-22 \text { IV }\end{array}$ & $\begin{array}{l}3.67 \\
3.28\end{array}$ & $\begin{array}{l}17.2 \\
17.6\end{array}$ & $\begin{array}{l}45.4 \\
47.1\end{array}$ & $\begin{array}{l}848 \\
759\end{array}$ \\
\hline Skarb & $\begin{array}{l}\text { 7-12 IV } \\
17-22 \text { IV }\end{array}$ & $\begin{array}{l}4.21 \\
3.93\end{array}$ & $\begin{array}{l}17.4 \\
18.3\end{array}$ & $\begin{array}{l}47.2 \\
49.4\end{array}$ & $\begin{array}{l}925 \\
880\end{array}$ \\
\hline
\end{tabular}

Table 6.

Effect of sowing date on the characters of spring barley cultivars tested in 2009-2010

\begin{tabular}{|c|c|c|c|c|c|}
\hline Cultivar & Sowing date & $\begin{array}{l}\text { Productive } \\
\text { tillering rate }\end{array}$ & $\begin{array}{c}\text { Number of grains } \\
\text { per ear }\end{array}$ & $\begin{array}{l}1000 \text { grain } \\
\text { weight }(\mathrm{g})\end{array}$ & $\begin{array}{c}\text { Grain yield } \\
\left(\mathrm{g} \times \mathrm{m}^{-2}\right)\end{array}$ \\
\hline Afrodite & $\begin{array}{l}\text { 7-12 IV } \\
17-22 \text { IV }\end{array}$ & $\begin{array}{l}3.62 \\
3.34\end{array}$ & $\begin{array}{l}17.3 \\
18.8\end{array}$ & $\begin{array}{l}48.6 \\
47.8\end{array}$ & $\begin{array}{l}874 \\
841\end{array}$ \\
\hline Aliciana & $\begin{array}{l}7-12 \text { IV } \\
17-22 \text { IV }\end{array}$ & $\begin{array}{l}3.38 \\
2.89\end{array}$ & $\begin{array}{l}18.9 \\
21.0\end{array}$ & $\begin{array}{l}48.7 \\
48.5\end{array}$ & $\begin{array}{l}898 \\
805\end{array}$ \\
\hline Bordo & $\begin{array}{l}\text { 7-12 IV } \\
17-22 \text { IV }\end{array}$ & $\begin{array}{l}3.18 \\
2.68\end{array}$ & $\begin{array}{l}20.8 \\
21.8\end{array}$ & $\begin{array}{l}48.2 \\
47.3\end{array}$ & $\begin{array}{l}933 \\
804\end{array}$ \\
\hline Skald & $\begin{array}{l}7-12 \text { IV } \\
17-22 \text { IV }\end{array}$ & $\begin{array}{l}3.40 \\
3.11\end{array}$ & $\begin{array}{l}19.1 \\
19.8\end{array}$ & $\begin{array}{l}4.77 \\
48.6\end{array}$ & $\begin{array}{l}895 \\
833\end{array}$ \\
\hline Suweren & $\begin{array}{l}7-12 \text { IV } \\
17-22 \text { IV }\end{array}$ & $\begin{array}{l}4.12 \\
3.63\end{array}$ & $\begin{array}{l}16.9 \\
18.5\end{array}$ & $\begin{array}{l}46.2 \\
47.3\end{array}$ & $\begin{array}{l}932 \\
884\end{array}$ \\
\hline
\end{tabular}

The present study results confirmed the assumptions of the research hypothesis. The different response of the tested cultivars to sowing date as expressed by grain yield was associated with intervarietal variation in the main characters determining grain yield.
The best-yielding cultivars, 'Suweren' and 'Skarb', followed by 'Rufus', 'Kormoran', and 'Afrodite', produced a higher number of ears per unit area than the other cultivars and showed higher tolerance to delayed sowing date. The cultivars 'Conchita', 'Aliciana', 
and 'Bordo' were characterized by lower tillering ability, which, coupled with a shortening of the tillering stage and other growth stages in the case of delayed sowing date (Table 1), generated too small a number of ears in the crop. Among the grain yield components, number of ears per unit area is most strongly positively correlated with yield (P e c i o, 1995; N ow o r o ln i k, 2003).

In the literature, there is a lack of information on the response of new cultivars to delayed sowing date as expressed by plant morphological characters, grain yield, and plant phenology. Earlier national studies (F a t y g a et al. 1993; P e cio, 1995; Ku ku ła and Pecio, 1998; Noworolnik and Leszczyńska, 1998, 2001; Maćkowiak et al. 2000; Now o r o lnik, 2003) and foreign studies ( $\mathrm{Zh} \mathrm{a} \mathrm{o} \mathrm{et} \mathrm{al.}$ 1988; A ufhammer and Kubler, 1989; Lauer and Partridge, 1990; Weston et al. 1993; Conry, 1995) compared the degree of tolerance to delayed sowing date of old cultivars which are not grown nowadays. The above-mentioned studies found a different negative response of these cultivars to delayed sowing time as expressed by grain yield, but they did not analyse the relationship of this response with the degree of productive tillering and productivity characteristics of the ear. In the experiments carried out by the Research Centre for Cultivar Testing $(\mathrm{N} \mathrm{a} \mathrm{j}$ e w s k i , 2010), grain yields of all cultivars included in the national register in a given year were compared and also selected commercially important and biometric traits of these cultivars were determined. Among the main grain yield components, only 1000 grain weight was determined. The determination of productive tillering rate and number of grains per ear in the new cultivars made in this study is a unique exercise.

The determination of productive tillering rates for plants of the new cultivars tested in the present study may suggest tolerance of a given cultivar to delayed sowing date and its requirements concerning the seeding rate. Cultivars with higher tillering ability may be more tolerant to delayed sowing date and may require a lower seeding rate. The research on the effect of seeding rate on yield of various spring barley cultivars has found a stronger positive response of cultivars with lower tillering ability to increasing seeding rate $(\mathrm{A} \mathrm{u}$ fhammer and Kubler, 1989; Noworolnik, 2003, 2010 a).

\section{CONCLUSIONS}

1. Among the spring barley cultivars tested: 'Conchita', 'Kormoran', 'Rufus', 'Skald', 'Skarb', 'Afrodite', 'Aliciana', 'Bordo', and 'Suweren', there were large differences in productive tillering, number of ears per unit area, and grain yield. Smaller differences related to number of grains per ear and 1000 grain weight.

2. The cultivars 'Suweren' and 'Skarb' were characterized by high grain yield thanks to greater plant tillering and higher number of ears. The cultivar 'Bordo' was marked by the highest number of grains per ear, while cv. 'Kormoran' had the highest 1000 grain weight.

3. A delayed sowing date caused a shortening of the growing season by 8-9 days and there was a shortening of all plant growth stages. This negatively affected number of ears per unit area and grain yield in all the cultivars, but did not result in significant changes in number of grains per ear and 1000 grain weight.

4. 'Suweren' and 'Skarb', i.e. cultivars with higher tillering ability, can be considered to be cultivars more tolerant to delayed sowing date (which show a lower decrease in yield).

\section{Acknowledgements}

Research supported by the Ministry of Science and Higher Education of Poland as the part of statutory activities of Research Institute of Soil Science and Plant Cultivation, State Research Institute.

\section{REFERENCES}

Aufham mer W., Kubler E., 1989. Zur Leistungfahigkeit von Gerste in Abhangigkeit von Form und Sorte sowie von Standort und Produktionstechnik. Bodenkultur, 40 (1): 47-60. (in German)

Conry M.J., 1995. Comparison of early, normal and late sowing at three rates of nitrogen on the yield, grain nitrogen and screenings content of Blenheim spring malting barley in Ireland. J. Agric. Sci. Cambridge, 125: 183-188.

Fatyga J, Chrzanowska-Drożdż B., Liszewski M., 1993. Wpływ terminów siewu na wysokość plonów ziarna i słomy jęczmienia jarego. / The effect of sowing date on grain and straw yields of spring barley. Rocz. Nauk Rol. 109 (4): 143-152. (in Polish)

Kukuła S., Pecio A., 1998. Wpływ wybranych czynników agrotechnicznych na plon i jakość ziarna browarnych odmian jęczmienia jarego. / The effect of some agronomic factors on grain yield and quality of spring malting barley. Pam. Pul. 113: 53-60. (in Polish)

Lauer J.G., Partridge J.R., 1990. Planting date and nitrogen rate effect of spring malting barley. Agron. J. 82 (6):1083-1088.

Maćkowiak W., Budzianowski G., Goworko W., Woś H., 2000. Reakcja odmian zbóż jarych : pszenżyta, owsa, pszenicy i jęczmienia na termin siewu. / Response of cultivars spring cereals: triticale, oat, wheat and barley, to sowing date. Fol. Univ. Agricult. Stetin, Agricult. 82: 159-162. (in Polish) 